\title{
Challenges for the Local Governance in the Republic of Kosovo
}

\author{
Mervete Shala Phd (c) \\ Lecturer Msc. Mervete Shala Phd (cand.) University Haxhi Zeka Peja Kosovo, Lecturer College of Dukagjin Peja \\ Email: mervete.shala@unhz.eu
}

\section{Doi:10.5901/ajis.2015.v4n3s1p661}

\section{Abstract}

This paper will deal with the challenges of local government in Kosovo from the time of international administration of UNMIK (after the end of the war) up to the construction of democratic decentralized system of local government, difficulties of political changes and human and financial resources. After the war ended in 1999, Kosovo was placed under international administration. Kosovo was faced with multiple challenges such as poor economy, transformation of state planned economy to a market economy, the low economic development, political transformation from a socialist system to a democratic system and the transfer of power from the provision Institutions of UNMIK to the independent Kosovo institutions. The aim of this paper is to analyze and tackle challenges of local government such as the lack of legal regulations and approval for local government, the establishment of new municipalities, reform of the local governance, the establishment of the association of municipalities distinguishing association of Serb majority municipalities in Kosovo. What was the role of the international community in the establishment and organization of local governance? What challenges accompanied the process of local government? In Kosovo, the reform of local governance was a very sensitive, complicated and sometimes unstable process as a result of political development but that has proved to be successful. Challenge for Kosovo institutions was integration of the three northern municipalities with Serb community in local self-government system, although construction and development departments of local self-government system was based on the principles of European values for the local government. One of the main challenges for the future will be the foundation of the Association of Serbian majority municipalities in northern Kosovo who claim that this association have the powers of a legal entity, independent from Kosovo. The methodology of the research will be mixed like: descriptive method, research, explanatory methodology, predictive methodology.

Keywords: local administration, good governance, decentralization, reform, accountability

\section{Introduction}

Kosovo after the war 1999 was set under temporary administration of the United Nations (UNMIK) .In the beginning all the powers: legislative, executive and judiciary was exercised by the Special Representative of the Secretary-General. Due to the efficient administration of Kosovo Special Representative of the Secretary-General appointed regional and municipal administrators to lead the local administrations. UNMIK, ruled, and helped in consolidation of central and local institutions in Kosovo. Organization and functioning of local self-government, during this period had faced various challenges such as: the destroyed municipalities, establishment of new municipalities in the beginning as a pilot projects, reform of local government, expansion of fiscal autonomy in municipalities, functioning and financing of parallel structures from Republic of Serbia in some municipalities and non-integration of the Serb community, etc.

Society and political class of Kosovo was committed to building a democratic system of government and for the building of local self-government system based on values and European standards for local government to adapt to the needs and development of the country without considering the challenges that they might have faced during the process.

This paper is structured as follows: in the first part we analysed the historical aspect of the development of local governance in Kosovo from ancient times until the present time. In the second part we have reviewed the relevant literature and legal standards that directly or indirectly have contributed to the local government after the war of 1999 during the period of administration of Kosovo by UNMIK and the government after the Declaration of Independence of Kosovo.In the third section we have analysed regional and international experiences to local government a comparative review of local government in some EU countries. The research methodology is relies on primary sources and secondary sources such as literature, analysis of all legal documents on which local self-governance in Kosovo and the Local Ministry of Administration reports. In the end, we have presented the conclusions and recommendations. 


\section{Background of the Development of Local Governance in Kosovo}

Throughout the history in general in Kosovo we have distinguished two types of local government, one-level local government and multi-level.

Multi-level local governments were: settlements (prehistory), cities (in ancient) and municipalities (XX century). Local government was composed of: city and principalities (the Middle Ages), sangjaqe (districts), kaza (municipalities), neighbourhood and villages (in Turkish Empire); counties (provinces, Banovina), Rethet (circles), municipalities, cities (XX c.) (History and Territorial Administrative Arrangement Kosovo, 2014, p.1). The form of territorial administration from 1945 to 1999, there was great movement, but can be summarized in three main periods:

1) The period of nationalization of land;

2) The periods of local government reform and

3) The period the suppression of legitimate local government bodies.

Nationalisation of the land was performed through agrarian reform 1945 - 1958, where the property and land was mostly reduced in private property and free market economy. The reform of I local government wens through several stages: the organization of local government in two levels, district and municipality (1945 -1958) and the organization of local government in one level -the municipality (1959 -1990) The number of districts was initially reduced from 17 (1947) to 5 in districts (1957) Territorial in municipalities was initially centralized, then in 1952/53, was completely decentralized in the type of small municipalities (204 municipalities) Seeing that this was a huge administration and a great burden for the state, than it moved in the form of territorial organization with relatively large municipalities (22 municipalities), and again to switch to medium municipalities (30 municipalities). From the year 1989/90, Serbia suspended $f$ central Kosovo authorities and too $\mathrm{k}$ the competences of municipalities and transferred them at the level of counties (5 regions) and centralized them also. (Ibidemd, pg.37). Organizing a local government had been levelled even before 1999, according to the socialist system( Organization and functioning of local self-government in Kosovo, 2013, pg. 26).

How was the local government organized after the war from 1999 in Kosovo? On 12 June 1999 Kosovo was liberated by the Serbian occupation with the direct involvement of NATO, and set under administration of the United Nations. After the war in Kosovo local administration created the United Nations (UN) in five regional administrations that were consistent with areas of multinational brigades of KFOR. Even though UNMIK doesn't recognize the regional level as a form of local government.

In 1999 year Special Representative of the Secretary-General appointed, the Regional Administrator and Municipal Administrators for Leadership of the local Administration. In year 1999 Special Representative of the Secretary-General appoint, Regional Administrator and Municipal Administrators for leadership of the local administration (Regulation no. 1999/14). Also, establishment of the administration took time It was not until January 2000 that the bare minimum of UN staff had been deployed for municipal administrations throughout Kosovo, although a good many posts remained unfilled even then. For the first year or so, international efforts to establish local administration were encumbered by slow deployments of Pillar II officials into the municipalities; by their frequent inexperience in local government; by the absence of clear central direction on the structures and processes of desirable municipal governance; by disagreements between regional leaderships in the UN's Pillar II Administration, the OSCE's Pillar III Institution Building and KFOR in the early phases of operation; and by difficulties in cooperating with emerging local administrations (Baskin,2004, p.13). The Kosovo legal continuity had been recognized after the establishment of the international administration of UNMIK in Kosovo in 1999, while the local self-government system remained unchanged and thus inheriting one-tier local selfgovernment system. Kosovo has had 30 municipalities in total. Based on the chronological aspect of local selfgovernment development, local self-government in Kosovo has historically changed its form due to circumstances of social, economic and political development (Strategy on Local Self-Government 2015-2025, p.10). Establishing an international protectorate Kosovo found lacking legal to organize and regulate local government. The UNMIK Regulation No. $2000 / 45$ on the Self-Governance in Kosovo was the first regulatory act with legal supremacy that established the foundations of a system of democratic local self-governance in service to the citizens in the state of Kosovo (Progress report on implementation of decentralization 2012, p.17). Legal regulation of issues related to decentralization and advancement of administration and municipal government in Kosovo may be divided into three periods, such as:

Period during which municipalities were administered under Legal Regulations from UNMIK Administration,with a certain Municipal Administrator (UNMIK Regulation No.1999/14 and UNMIK Regulation No. 2000/45);

Period during which municipalities were administered under Legal Regulations from UNMIK Administration, but without International Municipal Administrator (UNMIK Regulation No. 2003/11 and UNMIK Regulation No. 2007/30); and

Period of local self-government according to the laws issued by the Assembly of the Republic of Kosovo (Law on 
Local Self-Government), (Progress Report on implementation of decentralization 2012,p.13 )

In 1999, following deployment of the international administration (UNMIK) in the Republic of Kosovo and election of domestic democratic institutions at the central and local levels, there had begun set up of these institutions and gradually was initiated progressive transfer of responsibilities from international authorities to the local ones (MLGA Progress Report, 2012, 10).

\section{Local Self-Government Prior to Declaration of Independence of Kosovo}

After the liberation Kosovo was set under the administration of the United Nations Mission. Kosovo after the liberation, the first phase of creation of self-government began with the adoption and promulgation of Regulation No. 2000/1 on the Kosovo administrative interim joint structure Article 1 outlines that Kosovo structures, be they executive, legislative or judicial (such as the Provisional Government of Kosovo, Presidency of the Republic of Kosovo), shall be transformed and progressively integrated, to the extent possible and in conformity with the present regulation, into the Joint Interim Administrative Structure, which should be operational by 31 January 2000 by which time these and all other Kosovo structures of an executive, legislative or judicial nature shall cease to exist. All communities of Kosovo shall be involved in the provisional administrative management through procedures set out in the present regulation with a fair representation of all communities. Referring to the Regulation Article 1 outlines that representatives of political forces of Kosovo share provisional administrative management with UNMIK.The Special Representative of the Secretary-General retains legislative and executive authority (Regulation No. 2000/1). The main principles governing this structure were: that Kosovo political forces and UNMIK shared the administrative management; that all administrative decisions were in conformity with the applicable law in Kosovo; and that all communities were fairly represented. (OSCE, Implementation of Kosovo Assembly Laws by the Executive Branch,2005,p.7) Organization and functioning of local authorities until Declaration of Kosovo's Independence, was regulated with regulations issued by UNMIK administration deployed in Kosovo after the end of the war in 1999. We have divided periods of approval of legal changes on local self-government into two periods:

1. The first period started as of 2000 (with holding of the first local elections) and ended in 2007 (with essential legal amendments) and

2. The second period started as of 2007 (with holding of new elections organized by domestic institutions and after political changes in the country), up to issuing and approval of legislation on local self-government by independent institutions of the Republic of Kosovo.

In August 2000, the SRSG promulgated the UNMIK Regulation No. 2000/45 on Self Government of Kosovo Municipalities. This regulation is considered as the first legislative act that establishes the foundations of a democratic local government and that will be in the service of citizens in the state of Kosovo. (MLGA,Progress report on implementation of decentralization,2012,p.13). With this regulation were set the foundations of administrative and territorial organization of local government in Kosovo, in accordance with the European Charter of Local SelfGovernment. (History and Territorial Administrative Arrangement Kosovo, Pristina, 2014, pg.39). The basis for the functioning and organization of local government in Kosovo at the time was the UNMIK Regulation on Municipal govern,with this regulation, in accordance with United Nations Security Council resolution 1244, establishes provisional institutions for democratic and autonomous self-government at the municipal level as a step in the progressive transfer of administrative responsibilities from United Nations Interim Administration Mission in Kosovo (UNMIK), which will oversee and support the consolidation of these institutions. Referring to the Regulation Article 2 outlines that the basic territorial unit of local self-government in Kosovo shall be the municipality, which shall exercise all powers not expressly reserved to the Central Authority. Municipalities shall regulate and manage public affairs in their territory within the limits fixed by law and so as to ensure conditions for a peaceful and normal life for all inhabitants of Kosovo. They may attend to matters of general concern that are connected with the municipality and that are not to be attended to solely by the Central Authority or another body (Regulation No. 2000/45 section 1 and section 2). The highest representative body of the municipality shall be the Municipal Assembly and it shall be directly elected. The powers and duties of the municipality shall be exercised and performed solely by the Municipal Assembly and its organs. Referring to the Regulation provide the number of members of the Municipal Assembly of the municipalities in the boundaries of the municipalities. (Regulation No. 2000/45 Article 10). The Kosovo legal continuity had been recognized after the establishment of the international administration of UNMIK in Kosovo in 1999, while the local self-government system remained unchanged and thus inheriting one-tier local self-government system. First free and democratic elections for local government were held in 2000. The UNMIK Regulation on Self-government of Municipalities was the basis for the functioning and organisation of 
local government in Kosovo while according to UNMIK Regulation on the Number, Names and boundaries of Municipalities, Kosovo has had 30 municipalities in total. Afterwards, the main principles of local self-government have been guaranteed in 2001 by the Constitutional Framework, 2002 was again a year of elections, while in 2004; the Framework Agreement on the beginning of the local government reform process has been approved (Strategy on Local Self-Government 2015-2025, p.10).

Although these two UNMIK Regulation 2000/45 (and follow-on regulations for amendment of the same) and Regulation 2007/30, were the basis of the functioning of local government which determined powers of municipalities. Withe adoption of Regulation 2007/27 on Local Elections in Kosovo, became the first step towards local government reform. According to this regulation, citizens were entitled to directly vote their candidate for the mayor. Later UNMIK promulgated the Regulation no.2007/30 amended UNMIK Regulation No. 2007/45. With Regulation 2007/30, in addition to changes on the organization and functioning of local self-government, it strengthened the position of the Mayor as the highest executive. The elected Mayor of the Municipality elected directly the citizens of the municipality with the right to vote.(Regulation No. 2007/30 amending UNMIK regulation No. 2000/45 Article 24). Reform of local government in Kosovo became a prominent issue in October 2002,when the then Special Representative of the Secretary-General of the United Nations, Michael Steiner, promised to decentralise local government structures in the hope of encouraging the Serb community to take part in local elections (KIPRED, Local Government and Administration in Kosovo 2004, p. 10).

The reform of local government began after installing of the UN administration (UNMIK), mainly as political decentralization in order to integrate the Serbian community in Kosovo's governing systemDecentralization became a priority of the international community in Kosovo, especially after March 2004. A key element of the political dimension of decentralization was 'creation of independent political entities, municipalities, autonomous with their elected politicians "Despite the fear that decentralization could jeopardize territorial boundaries of the country, the fact that the Serb community had hitherto boycotted the entire political process in Kosovo, and yet more politically integrated in Serbia than in Kosovo, this political demand by the international community quickly became a priority of the Provisional Institutions Self-Government in Kosovo (PISG), respectively Government of Kosovo. In July 2004, the latter formed a working group for related to this aim, headed by the Minister of Public Services Jakup Krasniqi, a group have which drafted a framework document for decentralization, a document which however, it was focused only on the political aspects, without specifying any time and spatial frame (ie new municipalities to be formed), (Decentralization in Kosovo, experiences from the municipalities of Prizren Region, December 2009, p.4-5). For the first time, the territorial reform begun with the creation of several new municipal units. Framework agreement, envisaged the establishment of five Pilot Municipal Units (creation of three pilot municipal units was achieved, while the other two were not functional due to the political situation in Kosovo). In 2007 the second reform related to the election reform for local government in institutional terms has occurred, whose aim was to promote local democracy in the country. This time citizens had directly elected the Mayors of Municipalities.On the occasion of the declaration of independence in 2008, the Assembly of Kosovo has adopted the Constitution of the Republic of Kosovo and the set of basic laws for the organisation of local self-government in Kosovo (Strategy on Local Self-Government 2015-2025, p.11).

Decentralization has mainly been political from top-down by International Community. Initially it was announced by the United Nations Mission in Kosovo, the one of after the 1999 war (Mitrovica). But a serious consideration had taken only after the Kosovo status negotiations led by Martti Ahtisaari. During the status talks and discussion of decentralization in the upper level, beneficiaries and municipalities of this process are not consulted.Decentralization in Kosovo was followed by challenges because it was very clear on paper, while in practice during implementation there were numerous objections, followed by protests, and all this because of lack of appropriate information to the public about decentralization process, lack of work of political parties with electorate.(Ferati, 2013,p.14).

\subsection{Local Self-Government after the Declaration of Independence of Kosovo}

Governance of the country is organized in two levels: the level of central government (CG) and local level (LG). Central government develops and implements state policies for the development and protection of the country, while local governments implement policies of central and local service to its citizens. The Republic of Kosovo lies in an area of $10908 \mathrm{~km} / 2$, which is divided into 38 administrative units in 38 or municipalities that lies and act in specific territorial conditions. (Organization and functioning of local self-government in Kosova, 2013, p. 25). Based on the number of residents, municipalities can group into four (4) groups: the first group of municipalities with over 60,000 inhabitants, the second group, municipalities with over 30,000 inhabitants, a third group of municipalities with over 5,000 inhabitants and fourth group municipalities with less than 5,000 inhabitants. (Ibidem, p. 28). Constitution of the Republic of Kosovo in 
Chapter X, guaranteed Local Government and Territorial Organization. Based on Article 123 of the Constitutio provide General Principles of Local Government.The right to local self-government is guaranteed and is regulated by law.Local self-government is exercised by representative bodies elected through general, equal, free, direct, and secret ballot elections. The activity of local self-government bodies is based on this Constitution and the laws of the Republic of Kosovo and respects the European Charter of Local Self-Government. The Republic of Kosovo shall observe and implement the European Charter on Local Self Government to the same extent as that required of a signatory state.Local self-government is based upon the principles of good governance, transparency, efficiency and effectiveness in providing public services having due regard for the specific needs and interests of the Communities not in the majority and their members. Also article 124 of the Constitution outlines that the basic unit of local government in the Republic of Kosovo is the municipality. Municipalities enjoy a high degree of local self-governance and encourage and ensure the active participation of all citizens in the decision-making process of the municipal bodies. Establishment of municipalities, municipal boundaries, competencies and method of organization and operation shall be regulated by law. Municipalities have their own, extended and delegated competencies in accordance with the law. The state authority which delegates competencies shall cover the expenditures incurred for the exercise of delegation.Municipalities have the right of intermunicipal cooperation and cross-border cooperation in accordance with the law. Municipalities have the right to decide, collect and spend municipal revenues and receive appropriate funding from the central government in accordance with the law. Municipalities are bound to respect the Constitution and laws and to apply court decisions. The administrative review of acts of municipalities by the central authorities in the area of their own competencies shall be limited to ensuring compatibility with the Constitution of the Republic of Kosovo and the law. (Constitution Articles 123 and 124). Law Nr. 03/I-040 on local self government provide the legal status of municipalities, their competencies and general principles of municipal finances, organization and functioning of the municipal bodies, the intra-municipal arrangements and the intermunicipal cooperation including the cross border cooperation and the relationship between municipalities and central government. (Law Nr. 03/l-040 Article 2). After the independence in 2008 the basic legal basis for the construction and operation of local self government is Constitution of the Republic of Kosovo. Also, Basic laws for local government are: Law No.03/l-040 on local self government, Law No.03/l-049 on local government finance, Law No.03/l-041 on administrative municipal boundaries, Law No.03/I-072 on local elections in the Republic of Kosovo, Law No. 03/L-090 on public-private-partnerships and concessions in infrastructure and the procedures for their award, Law No.04/L-111 on amending and supplementing the Law No.03/l-087 on publicly owned enterprises, Law No.04/L-144 on allocation for use and exchange of immovable property of the municipality, Law No.04/L-110 on construction, Law No.04/L-147 on Waters of Kosovo, Law No. 03/L-087 on publicly owned enterprises. The current legal framework has given a complete autonomy to the Local Government bodies. Decentralization of power, local government reform, gaining a high degree of autonomy in the governance of municipalities, it has impacted to the integration of the Serb community and the creation of a stable and unified policy in country. Thus the system has achieved three main objectives:1) establishment of the state with a stable multi-ethnic society; 2 ) integration of communities (in particular the Serb community) in self-governing institutions ofthe country and 3) provision of quality services to citizens.Citizens have equal rights to choose their own representatives, to govern and to serve them and dismiss them if do not govern well with their assets. So, the power of local government derives only from the will of the citizens, excluding any possibility of interference from above, with the exception of the competent courts when Local Government bodies violate the law. However, the central institutions without legal support have built the administrative structures between central and local government, wanting to provide assistance to Local Government, in providing of more quality services to citizens.(Organization and functioning of local self-government in Kosova, 2013, p. 6).

The Central Government's stated support for decentralization suggests an opening for strengthening municipal administrations to advance to a higher level of accountability to their constituents, especially as concerns financial management and development of own source revenue. (USAID/Kosovo Country Development Cooperation Strategy 2014-2018, p.9).

The aim of the Government of Kosovo after the Declaration of Independence was the creation of a stable and effective system of local government throughout the territory of Kosovo that would provide better living conditions for all its citizens paying adequate care to special needs and concerns of minority communities in Kosovo. Challenges for Kosovo were reforming of local government legislation, the establishment of new municipalities, the transfer of powers and municipality resources. Capacity building of municipalities in coordination with donors, to develop contacts with the public in order to communicate the benefits of decentralization and accomplish local government reforms in the municipalities of northern Kosovo. (Action Plan for the implementation of decentralization 2010-2011 p.2). As stated above, organization and functioning of local self-government during its process it has encountered certain challenges, 
such as the establishment of the new municipality of Northern Mitrovica, operation and financing of parallel structures from Serbia in several municipalities, local government reform will continue in the coming years, since the establishment of new municipalities and the delegation of powers towards the local level can only be considered as the first stage of the whole project to reform the local government in Kosovo.Extension of fiscal autonomy in municipalities that will establish and collect local taxes and fees themselves. Building an efficient public administration, which means a stable administration, devoted to law enforcement and to provide better services for the citizens. Exercising of powers in the field of education, health, environment, social services and the transfer of property management public, public enterprises, social and cultural (Musmurati,2011). Challenge for Kosovo institutions is the demand of the Serb community for the establishment of a separate Serbian Association of municipalities and requirements of Serbia state during the Kosovo-Serbia talks in Brussels that the association of Serbian municipalities to have the authority to extend their legislative bodies, executive and funding Directly from the state of Serbia in competition from other association in other municipalities in Kosovo which are functioning in function.

\subsection{Autonomia and Local Government Competencies of Kosovo}

Territorial governance, respectively, the territorial governance is a very complex process and can be said to consist of several functions, respectively activities. (Stavileci, 1997, p. 247) . European Charter of Local Self-Government obligate state the principle of local self-government shall be recognised in domestic legislation, and where practicable in the constitution. (European Charter of Local Self-Government). European Charter of Local Self-Government Article 3 outlines that local self-government denotes the right and the ability of local authorities, within the limits of the law, to regulate and manage a substantial share of public affairs under their own responsibility and in the interests of the local population. This right shall be exercised by councils or assemblies composed of members freely elected by secret ballot on the basis of direct, equal, universal suffrage, and which may possess executive organs responsible to them. (Article 3 ). Referring to the European Charter of Local Self-Government Article 4 outlines that the basic powers and responsibilities of local authorities shall be prescribed by the constitution or by statute.Local authorities shall, within the limits of the law, have full discretion to exercise their initiative with regard to any matter which is not excluded from their competence nor assigned to any other authority. Public responsibilities shall generally be exercised, in preference, by those authorities which are closest to the citizen. Allocation of responsibility to another authority should weigh up the extent and nature of the task and requirements of efficiency and economy.Powers given to local authorities shall normally be full and exclusive. They may not be undermined or limited by another, central or regional, authority except as provided for by the law.Where powers are delegated to them by a central or regional authority, local authorities shall, insofar as possible, be allowed discretion in adapting their exercise to local conditions.Local authorities shall be consulted, insofar as possible, in due time and in an appropriate way in the planning and decision-making processes for all matters which concern them directly (European Charter of Local Self-Government). The right to local self-government is guaranteed and is regulated by law (Constitution of the Republic of Kosovo article 123 paragraph 1). However, but in order for municipality to be able to deliver good services it must have considerable autonomy to operate in central government institutions must be in a position to offer technical assistance and support and oversee that the laws are not being breached (Decentralization a heavy weight to be carried out, 2011, p.20). The legal framework in Kosovo has changed several times from 2000 to 2008, arranged progressively powers of municipalities, while allowing higher authority in local self-government. Therefore, municipalities, municipal bodies respectively won a higher degree of autonomy in their work, which instead of leading it to a local self-government, it placed it to more local autonomy. (History and Territorial Administrative Arrangement Kosovo, Pristina, 2014 pg.50). The municipalities shall exercise its competences in accordance with the principle of subsidiary. Municipalities shall exercise own, delegated and enhanced competencies in accordance with the law ( Law No 03/L-040 articles 15 and article 16 ).

\subsubsection{Own Competencies}

With UNMIK Regulation no. 2000/45 amended by UNMIK Regulation no. 2007/30 and then to the Law on Local Government have defined the same powers for all municipalities of Kosovo. Competences were not described and specified with a special legal or sub-legal act. In general the law required from municipalities to provide equal access to public services for citizens; to ensure minimum quality and quantity standards in the provision of public services; minimum qualifications of personnel and their training and provide general principles on licensing and accreditation of public service providers. Description of these powers, the various line ministries, was not carried out in the best possible 
way. In certain aspects there were duplication in some contradictions and difficulties of implementation in practice. However, by the Regulation of the year 2000 until the adoption of the law in 2008, municipalities received higher powers, including powers for some central Serbian majority municipalities. (History and Territorial Administrative Arrangement Kosovo,Pristina, 2014). Municipalities shall have full and exclusive powers, insofar as they concern the local interest, while respecting the standards set forth in the applicable legislation in the following areas: local economic development,urban and rural planning, land use and development, implementation of building regulations and building control standards, local environmental protection. Provision and maintenance of public services and utilities, including water supply, sewers and drains, sewage treatment, waste management, local roads, local transport, and local heating schemes, local emergency response. Provision of public pre-primary, primary and secondary education, including registration and licensing of educational institutions, recruitment, payment of salaries and training of education instructors and administrators; promotion and protection of human rights; provision of public primary health care. Provision of family and other social welfare services, such as care for the vulnerable, foster care, child care, elderly care, including registration and licensing of these care centres, recruitment, payment of salaries and training of social welfare professionals, public housing;public health. Licensing of local services and facilities, including those related to entertainment, cultural and leisure activities, food, lodging, markets, street vendors, local public transportation and taxis, naming of roads, streets and other public places. Provision and maintenance of public parks and spaces, tourism;cultural and leisure activities, any matter which is not explicitly excluded from their competence nor assigned to any other authority (Law No. 03/L-040 Article 17). For Example, responsibilities and Competencies of the Municipalities in Education was provided with the Law no. 2002/2 on primary and secondary education in Kosovo, municipalities accepted the responsibility of organizing the learning process at all levels of university-level education, but this law did not decentralized all powers of the authorities. Election of directors of primary and secondary education remains the liability of the Ministry of Education, Science and Technology (MEST). Also, managing on budget remains centralized in MEST and in the Ministry of Economy and Finance (Law No. 2002/2 Article 13 and Article 14). After the Declaration of Independence of Kosovo and consent some laws of competencies of the Municipalities in Education have the provisions of public pre-primary, primary and secondary education, including registration and licensing of educational institutions, recruitment, payment of salaries and training of education instructors and administrators. Municipalities shall be entitled to cooperate, within the areas of their own competencies in the field of education, with other municipalities and other authorities. This entitlement includes cooperation with municipalities and institutions, including government agencies, in the Republic of Serbia. Construction of educational facilities, registration and admission of students, employment of teachers and other school personnel in accordance with legal procedures for the recruitment, selection and employment of public employees; selection of the Director and/or Deputy Director of educational institutions in accordance with legal procedures for the recruitment and legal criteria's determined by MEST from a commission established by the Municipality which two members shall be from the Municipality and one from MEST. Registration, public health and safety inspection and licensing of pre-primary educational institutions, payment of the managerial staff as well as other employed personnel in accordance with Kosovo legislation,training educators and other professional staff.Supervision and inspection of the education process in accordance with guidelines established by the MEST. Reporting on preprimary level education, budgetary and management operations to municipal governments and the MEST in accordance with municipal and central legislation etc. (Law No. 03/L-068 Articles 4 and 5).

The Assembly of the Kosovo Republic consent, the Law No. 03 / L-068 on Education in the Municipalities of the Republic of Kosovo, Law No. 04 / L - 032 on Pre-University Education in the Republic of Kosovo and the Law No. 04 / L143 on adults Education and Training in the Republic of Kosovo made decentralization of operations in the education sector and municipalities took charge of the new responsibilities they did not have with the previous law.

\subsubsection{Delegated Competencies}

Apart from own competencies, municipalities in Kosovo have been delegated a limited number of powers from the central level, in order that for these types of services citizens may be served in the nearest municipality. The uniqueness of these municipalities is that when municipalities do not have the capacity to provide them, they can be withdrawn again by the appropriate central institution (History and Territorial Administrative Arrangement Kosovo, Pristina, 2014, p. 59). Central authorities in Republic of Kosova shall delegate responsibility over the following competencies to municipalities, in accordance with the law: cadastral records, civil registries, voter registration,business registration and licensing, distribution of social assistance payments (excluding pensions), and forestry protection on the municipal territory within the authority delegated by the central authority, including the granting of licenses for the felling of trees on the basis of 
rules adopted by the Government.Central authorities in Republic of Kosova may delegate other competencies to municipalities, as appropriate, in accordance with the law.Delegated competencies must in all cases be accompanied by the necessary funding in compliance with objectives, standards and requests determined by the Government of Kosova ( Law Nr. 03/L-040 Article 18). The aim of delegating competencies is providing of closer and better services to its citizens.

\subsubsection{Enhanced Municipal Competencies}

In Kosovo certain municipalities explained below shall have their own competencies enhanced in the areas of health, education and cultural affairs and shall have participatory right in selecting local station police commanders. Central authorities of Republic of Kosova shall monitor the exercise of enhanced competencies, in accordance with the central legislation providing for equal access to public services, minimum quality and quantity standards in the provision of public services, minimum qualifications of personnel and training facilities, general principles on licensing and accreditation of public service providers. Municipalities exercising enhanced municipal competencies may cooperate with any other municipality in providing services (Law No.03/L-040 Article 19). The municipalities of Mitrovica North, Gracanica, Štrpce shall have the competence for provision of secondary health care, including registration and licensing of health care institutions, recruitment, payment of salaries and training of health care personnel and administrators. The municipality of Mitrovica North shall have competence for the provision of higher education, including registration and licensing of educational institutions, recruitment, payment of salaries and training of education instructors and administrators (Article 20 and Article 21). Pursuant to Article 22 of the Law Nr. 03/l-040 on local self government outlines that all municipalities in which the Kosova Serb Community is in the majority shall have authority to exercise responsibility for cultural affairs, including, protection and promotion of Serbian and other religious and cultural heritage within the municipal territory as well as support for local religious communities in accordance with the applicable law. Municipalities may cooperate with any other municipality in cultural affairs. Also municipalities in which Kosova Serb community is in a majority shall exercise enhanced participatory rights in the selection of the local station police commanders in accordance with law on police (Law No. 03/L-040 Article 22 and Article 23). With these powers Serbian majority municipalities receive central authority and gain a high degree of autonomy for local self-government. In this case, a positive discrimination for the Serbian-majority municipalities is created, which resulted in political unifying of the Serb community with the institutions of the Republic of Kosovo and created the premise for the creation of local institutions along ethnic lines. (History and Territorial Administrative Arrangement Kosovo, 2014 p. 61).

\section{Regional and International Experiences for Local Government}

In democratic societies, the functioning of government systems and in particular local democracy is based on strong principles of interest and values to the local community and the general interests of the national and international level. Depending on the degree and circumstances of social and political developments, different countries have defined various principles for their governance in the local level, but generally possess some basic or vital principles, through which the character of governance is defined, as it is concluded in the document of evaluation of competencies of four EU countries (Madrid 2005), (Hambleton,2000), under which, local governments should be directed according to these main principles: self-government, proportionality, subsidiarity, diversity and flexibility (Organization and functioning of local Selfgovernment in Kosova 2013, p. 18). This right normally entails a representative assembly with or without executive bodies subordinate thereto, but allowance is also made for the possibility of direct democracy where this is provided for by statute (European Charter of Local Self-Government Explanatory Report Article 3 Paragraph 2). However, it is not possible, nor would it be appropriate to attempt, to enumerate exhaustively the powers and responsibilities which should appertain to local government throughout Europe (European Charter of Local Self-Government Explanatory Report Article 4 ). Regional states have different practices as regards to the organisation and functioning of local self-government of Kosovo.Local government is organized in the municipality and region(Slovenia), municipality and district level, where municipalities are divided into urban and rural areas (Croatia), the municipalities, municipalities and counties (Albania) and only in municipalities divided in urban and rural municipalities with a special city, composed of seven municipalities (Macedonia), (Strategy on Local Self-Government 2015-2025). The Constitution of the Republic of Albania article 108 outlines that Communes or municipalities and regions are the units of local government. Other units of local government are regulated by law. The territorial-administrative division of the units of local government is established by law on the basis of mutual economic needs and interests, and of historical tradition. Their borders may not be changed without first hearing the opinion of their inhabitants.Communes and municipalities are basic units of local government. They perform 
all the duties of self-government, with the exception of those that are given by law to other units of local government. Selfgovernment in the local units is exercised through their representative organs and local referenda (Constitution Article 108). Communes, municipalities and regions perform exclusive functions, shared functions and delegated functions (Law No.8652 Article 9). Croatia has a three-staged system of government, the organization of local government in the Republic of Croatia consists of 155 units of local government, where 428 of them belong to the municipal units, 127 units of the local second-level cities and 21 belong to third level or prefectures (Zupanja), this includes Zagreb. The powers of municipal governments units are specified by applicable laws, although Croatia's central power is concentrated, a large number of competencies that in reality does not talk much about elements of the decentralization of power. In city level like unit government, they perform powers in the fields of education at primary and secondary level, culture, social welfare and primary health care, construction, territorial civil protection and public services. ((Milloshević,2013). In Croatia There are two levels of sub-national government: cities and municipalities on the level of local self-government, and counties as the units of regional self-government.. Each local and regional government has its own statute stipulating the rights and responsibilities of local and regional public authorities inter alia the forms of consulting the citizens and the forms of cooperation. Citizens are involved in the decision-making process through public debates, consultation, and locally- or regionally-organized referenda (Eszter Hartay,Katerina Hadzi-Miceva Evans). The Constitution of the Republic of Hungary Article Article 41 outlines that the territory of the Republic of Hungary consists of administrative units including the Capital, the counties, cities, towns and villages.The Capital is divided into districts. Districts may be formed in other cities also (Constitution Article 41). All local authorities have the same fundamental rights However, the duties and responsibilities of local governments may be different. The rights and duties of local governments are determined by the law. The Courts protect the lawful exercise of jurisdiction by local authorities. Local governments are free to turn to the Constitutional Court for the protection of their rights. Citizens who have the vote exercise local government through the representative body they have elected and by local plebiscites. (Constitution Articles 43 and 44). The middle-tier oflocal government consists of nineteen counties. Budapest as the capital city of Hungary has a special legal status. There are no hierarchical relations between the municipalities and the counties. According to the Constitution, the fundamental rights of all local governments are equal. County local governments are not superior and do not have supervisory authority over the municipalities. The difference between these two lies in the administrative tasks delegated to each of them: counties provide public services that settlements are not capable of performing (Eszter Hartay,Katerina HadziMiceva Evans). In this paper we have treated local governance in several countries in the region and the EUcompetencies and responsibilities of local government in the state of Slovenia a comparative review of the powers of municipalities in Kosovo aiming not to overload the paper with other countries. For example, Local self-government Republic of Slovenia.Slovenians shall exercise local government powers and functions through self-governing municipalities and other local government organizations (The Constitution Article 138). Municipality shall be selfgoverning local government bodie. A municipality may comprise a single community or a number of communities whose inhabitants are bound together by common needs and interests. A municipality may be established by statute following a vote in favour of its establishment at a referendum conducted to ascertain the will of the people in the area affected. The territorial boundaries of a municipality shall be such as are prescribed by statute (Article 139 The Constitution of the Republic of Slovenia).. In Slovenia a municipality may, in accordance with laws, possess, acquire or have at its disposal all types of assets, establish and manage public enterprises and determine its budget within the system of public finances (The law on local self-government Article 20 ). Local matters of public interest (of the original tasks) determined by law or by the general act of a municipality shall be independently performed by the municipality. In order to satisfy the needs of its inhabitants, a municipality shall perform primarily the following duties and functions: manage the assets of the municipality; provide the conditions for the economic development of the municipality and in accordance with the law carry out tasks in the areas of catering, tourism and agriculture; plan spatial development, carry out tasks in the areas of encroachments in physical space and the construction of facilities in accordance with the law, and shall ensure the public service of the management of building land; create the conditions for the construction of housing and provide for an increase in the rent/social welfare housing fund; regulate, manage and provide for local public services within its jurisdiction; promote the services of social welfare for pre-school institutions, for the basic welfare of children and the family, and for socially threatened, disabled and elderly people; provide for protection of the air, soil and water sources, for protection against noise and for collection and disposal of waste, and perform other activities related to protection of the environment; regulate and maintain water supply and power supply facilities; create conditions for adult education, important for the development of the municipality and for the quality of life of its population; promote activities related to upbringing and education, information and documentation, associations and other activities on its territory; promote cultural/artistic creativity, ensure accessibility to cultural programmes, ensure library activity for general education 
purposes, and shall be responsible for preserving cultural heritage in its territory in accordance with the law; promote the development of sports and recreation; construct, maintain and regulate local public roads, public ways, recreational and other public areas; regulate traffic in the municipality and perform tasks of municipal public order;exercise supervision of local events; organise municipal services and local police, and ensure order in the municipality; provide for fire safety and organise rescue services; guarantee extrajudicial settlement of disputes; organise the performance of funeral and burial services; determine offences and fines for offences violating municipal regulations and inspect and supervise the implementation of municipal regulations and other acts, which it shall adopt to regulate matters falling under its jurisdiction, unless otherwise determined by law; adopt the statute of the municipality and other general acts; organise municipal administration; regulate other local matters of public interest (Article 21). Article 24 The law on local selfgovernment Republic of Slovenia predicts City municipalities shall also perform specific tasks which, in accordance with the law, fall under national jurisdiction and which apply to the development of towns. With respect to this, city municipalities shall, in particular: regulate local public transport; regulate the opening hours of catering facilities in their territories; perform tasks in the areas of encroachments in physical space and the construction of facilities in their territories; perform tasks in the area of the geodesic service; ensure a public network of grammar schools, and secondary, vocational and higher schools in their territories; ensure a secondary-level public health service in their territories. The state may by law vest in a municipality the performance of individual duties and functions from state jurisdiction (transferred tasks) subject to the prior consent of the municipality. Individual tasks which fall under national jurisdiction and which may be carried out more economically and more efficiently within municipalities may be transferred to municipal jurisdiction, especially in the areas of the regulation of local public transport, the opening hours of catering facilities, the implementation of tasks in the fields of encroachments in physical space, the construction of facilities and geodesic services, and the ensuring of a public network of grammar schools, secondary and vocational schools, as well as secondary-level public health services. It shall also be possible to legally determine that the implementation of individual tasks be transferred from national jurisdiction to all municipalities, city municipalities, municipalities located in a specific region, or individual municipalities. The reasons and conditions for transferring the implementation of individual tasks from national to municipal jurisdiction shall be prescribed by law. The implementation of individual tasks may be legally transferred from national to municipal jurisdiction on condition that the consent of all municipalities, all city municipalities or all municipalities located in a specific region to which the tasks are to be transferred be obtained. It shall be deemed that a municipality gives its prior consent if it submits an initiative for the performance of individual tasks that fall under national jurisdiction to the National Assembly. Before it adopts a law with which individual tasks are transferred from national to municipal jurisdiction, the National Assembly must obtain the prior consent of the relevant municipality. The state shall provide the municipality with appropriate means for the performance of duties and functions vested in it (Article 24).

\section{Conclusions}

Local governance in Kosovo faced many challenges since the efforts for constituting of the local administration. International institutions during the appointment of regional and municipal administrators and establishing local administration slow employment of Pillar II officials took quite a lot of time in municipalities; based on their frequent inexperience in local government; the lack of clear central directions for the structures and processes of desirable municipal governance; disagreements between regional leaderships in Pillar II of UNMIK (Administration), Pillar III (OSCE Institution Building) and KFOR in the early stages of operation; and the difficulties in cooperation just established local administrations. Another challenge was the transfer of authority from international to locals. Municipalities lacked human capacity, some newly established municipalities had neither the human resources nor the property, not able to provide their own revenues. Establishment of new municipalities was made on the basis of national affiliation of the requirements of the international community, in places where the Serbian community was living they were given a privilege to establish new municipalities, although did not meet the criteria required for the establishment of a new municipality.

Local institutions should provide sufficient space to employees to be more efficient in exercising of their power, organize training and capacity building seminars, in many areas that lack the capacity method was applied and practiced in European Union countries.

Local institutions should not politicize the civil staff, phenomena that have been occurring very early in our institutions, often showing problem and concerns for civil servants.

Local institutions devote more importance to depoliticize and professionalize local administration to have an efficient local administration more accountable, transparent and accountability which shall be in service to the citizens of 
the municipality.

Central institutions should not take quick decisions (election) for the formation of new municipalities without analysing if such municipalities have in disposal human resources and property to operate and develop.

Creation of new municipalities not to be performed according to ethnicity of the citizens, but to establish the criteria that is required to meet one place to be declared a municipality.

Both Associations of municipalities in Kosovo have the same powers and Associations of Serbian municipalities not to be recognized the right of legislative bodies, executive and to be funded directly by the state of Serbia. In fact, the reforming of local government in Kosovo, new established municipalities by the number of very low residents that have advanced power, large municipalities in Kosovo. The municipality should not be treated on the basis of ethnic affiliation of citizens, should not have positive or negative discrimination.

In the future and to amend the Law no. 03/L-40 on Local Self-Government, all major municipalities in Kosovo to be transferred own enhanced powers in health, education, and be eligible to participate in the selection of police station commanders and earn a high degree of autonomy for local government such is the case with some Serbian-majority municipalities.

\section{References}

Constitution of the Republic of Kosovo

European Charter of Local Self-Government

The Council of Europe 1986, European Charter of Local Self-Government Explanatory Report

Constitution of the Republic of Albania

The Constitution of the Republic of Slovenia,

The Constitution of the Republic of Hungary

Law No. 03/l-040 on local self government of the Republic of Kosovo

Law No. 2002/2 on primary and secondary education in Kosovo

Law No. 03/L-068 on education in the municipalities of the Republic of Kosovo

Law on organization and functioning of local governments the Republic of Albania"dated 31.07.2000

Law on local self-government Republic of Slovenia

Regulation No. 1999/14 on the appointment of regional and municipal administrators

Regulation No. 2000/45 on self-government of municipalities in Kosovo

Regulation No. 2000/1 on the Kosovo joint interim administrative structure

Regulation no. 2007/30 amending UNMIK Regulation no. 2000/45 on selfgovernment of municipalities in Kosovo

Kosovo Local Government Institute Local Governance Academy second generation, Boris Milloshević, Deputy Minister of Local Administration in the Republic of Croatia Reforms in the Republic of Croatia - challenges and prospects of European integration.with data: 24-27 Aprill 2013,

Kosovo Local Government Institute Local Governance Academy second generation Sadri Ferati, former Minister of Local Government, now Member of Parliament and member of the Parliamentary Committee on Local Government

Kosvo Institute for Policy Research and Development, Decentralization in Kosovo, experiences from the municipalities of Prizren Region, December

Kosovar Institute for Policy Research and Development Policy Research Series Paper \#4, Local Government and Administration in Kosovo Pristina, September2004, p. 10

Ministry of Local Government Administration (MLGA) Organization and functioning of local self-government in Kosova, August 2013, Pristina.

Ministry of Local Government Administration Strategy on Local Self-Government 2015-2025, Pristina, March 2014

Ministry of Local Government Administration, Progress Report on implementation of decentralization in the Republic of Kosovo Pristina, August 2012

Ministry of Local Government Administration, History of administrative and territorial organization in Kosovo LLSG April 3, 2014

Organization for Security and Co-operation in Europe Implementation of Kosovo Assembly Laws by the Executive Branch of the Provisional Institutions of Self-Government Review Period: Laws Promulgated in 2002-2003 January 2005

USAID/Kosovo Country Development Cooperation Strategy 2014-2018

Kosovo Local Government Institute Decentralization a heavy weight to be carried out , 5 July 2011

Eszter Hartay,Katerina Hadzi-Miceva Evans, Models for cooperation and participation on a local level: a comparative overview,Publisher: Macedonian Center for International Cooperaton

Robin Hambleton:"Modernising Political Management in Local Governments", 37 Urban Studies 931, 931 (2000)

Stavileci, Esat, Subscriptions Administrative. Institution of textbooks and teaching aids of Kosovo. Prishtinë, 1997

The Government of the Republic of Kosovo Action Plan for the Implementation of decentralization 2010-2011

Deputy Musmurati Basri. Minister for Local Government 05 September 2011 presentation to the Local Government Reform with the view widely https://mapl.rks-gov.net/getattachment/a697f9b8-1c74-4ba4-958a-1ff71284f2a3/Reforma-e-Pushtetit-Lokal.aspx 